\title{
Narrating the Treasury: What Medieval Iberian Chronicles Choose to Recount about Luxury Objects
}

\author{
Ana Rodríguez
}

\begin{abstract}
Chronicles written in the Kingdoms of Castile and León between the reigns of Alfonso VI and Fernando III, the period of greatest expansion against al-Andalus, assert the importance of the spoils of battle and the circulation of objects between Christian and Muslim lands, and between rival Christian institutions. The chronicles' accounts of the looting of churches by monarchs and nobles in the context of repeated internecine conflict give few details about pillaged objects. Rather, they define these pieces by materials without making note of individual characteristics; although certain objects did spark their interest, in most cases, the tales respond to the need to identify a given piece in order to construct a narrative. Their value comes not only from precious materials or the specialized work of their manufacture, but also from their ability to exemplify personal and collective virtues or defects, along with individual and family identities.
\end{abstract}

\section{Keywords}

Iberia - chronicles - narrative sources - Christian objects - Islamic objects

Some well-known lines from the Poem of Fernán González, written towards the mid-thirteenth century, are dedicated to the defeat of Almanzor

1 The author would like to thank Therese Martin, Principal Investigator of The Medieval Treasury across Frontiers and Generations: The Kingdom of León-Castilla in the Context of MuslimChristian Interchange, c. 1050-1200 (PI, Spanish Ministry of Economy and Competitivity, HAR2015-68614-P), and the Princeton Institute for International and Regional Studies at 
(Muhammad ibn Abī 'Āmir al-Manșūr, d. 1002) at the battle of Lara-a battle that never took place, nor did the reported encounter between the Muslim ruler and the count of Castile Fernán González (d. 970). ${ }^{2}$ This section of the poem recounts the enormous spoils taken by the Christians from the Muslims: goblets and vessels of gold, cases full of gold and silver coins, silk fabrics, swords, armor, and ivory caskets, the latter donated to the monastery of San Pedro de Arlanza:

With al-Mansur now a good distance away, the field was left well peopled with Christians; they gathered their possessions, granted them by God, and found such great wealth as to be beyond tally. They found in the tents an abundant treasure: many cups and goblets made of fine gold; such riches as no Christian or Moor had ever seen, - it would have sufficed Alexander and Porus. Many cases they found there, along with many bags, filled with gold and silver-no sign of copper coins-, many silken pavilions and many tents of war, breastplates and swords and a great mass of armor. They found caskets of ivory, very great in value, with other noble objects impossible to count; to San Pedro de Arlanza were most of them given, where to this day they are displayed upon its altar. ${ }^{3}$

Princeton University, for organizing and funding the conference at Princeton University in May 2017.

2 See Libro de Fernán Gonçalez, ed. Itzíar López Guil (Madrid: CSIC, 2001), 125.

3 The Poem of Fernán González, trans. Peter Such and Richard Ramone (Liverpool: Aris \& Phillips Hispanic Classics, 2015), verses 275-278: 175. "Quando fue Almançor / grand tiera alexado, finco de los cristianos / el canpo bien poblado; cojieron sus averes / que Dios les avie dado; tan grand aver fallaron / que non serie contado. Fallaron en las tiendas / sobejano tesoro, muchas copas e vasos / que eran d'un fino oro: nunca vio atal riqueza / nin cristiano nin moro, serien ende abondados / Alexander e Poro. Fallaron y maletas / e muchos de çurrones llenos d'oro e de plata, / que non de pepiones, muchas tiendas de seda / e muchos tendejones, espadas e lorigas / e muchas guarniçiones. Fallaron de marfil arquetas muy preçiadas, / con tantas de noblezas que non serien contadas; / fueron pora San Pedro las mas d'aquellas dadas,/ estan todas oy dia en su altar asentadas." On the objects and booty described in this fragment of the poem, see Juan Carlos Ruíz Souza, "Botín de guerra y tesoro sagrado," in Maravillas de la España Medieval: tesoro sagrado y monarquía, ed. Isidro Bango, 2 vols. (Valladolid: Junta de Castilla y León, 2001), 1:31-40. 
Just as it is easy for us to imagine what these ivory boxes from al-Andalus would have looked like, since some of them, converted into reliquaries, have been preserved in the treasuries of Christian churches, it is also easy to imagine the extent of the circulation of wealth represented by war and its spoils in Iberia throughout the central Middle Ages. Some of these objects, still held today in ecclesiastical institutions and museums, give evidence of such circulation. Written sources, particularly chronicles, offer a complementary view from the perspective of medieval scribes, which reveals the place of such luxury objects in the rulership strategies of Iberian kings and queens.

Chronicles written in the kingdoms of Castile and León between the reigns of Alfonso VI and Fernando III, the period of great expansion by the Christian kingdoms against al-Andalus beginning with the conquest of Toledo in 1085 and culminating in that of Sevilla in 1248, also assert the importance of the spoils of battle and the circulation of objects between Christian and Muslim lands as a result of war. The chronicle known as the Historia Silense or Historia Legionense (first third of the twelfth century), the Chronica Adefonsi Imperatoris (ca. 1145-1150), which centered on the reign of Alfonso VII, and the Chronica Najerense (last quarter of the twelfth century) all make copious references to wealth, gold and silver, precious fabrics and silks, as well as horses, coming from the booty obtained in battle. ${ }^{4}$ The opulence of the defeated Muslims and the great spoils acquired by the Christians is a constant presence in the multiple narratives of military campaigns. After the Christian victory at Las Navas de Tolosa in 1212, the archbishop of Toledo Rodrigo Jiménez de Rada, author of De Rebus Hispaniae (ca. 1240), eye-witness to the event, notes that:

Those who wished to loot found many things in the field, that is, gold, silver, rich garments, silk harnesses and many other valuable ornaments, as well as much money and precious vessels. ${ }^{5}$

4 Historia Silense, ed. Justo Pérez de Urbel and Atilano González (Madrid: CsIC, 1959); Chronica Adefonsi Imperatoris ed. Antonio Maya Sánchez, in Chronica hispana saeculi XII, Pars I, Corpus Christianorum Continuatio Mediaevaelis, 71 (Turnhout: Brepols, 199o), 109-248; Chronica Naierensis, ed. Juan A. Estévez Sola, Corpus Christianorum Continuatio Mediaevaelis, 72A (Turnhout: Brepols, 1995), $3^{-181}$. The discourse on spoliation is heavily represented in contemporary Arabic chronicles. See 'Abd al-Malik Ibn al-Kardabūs: Kitāb al-iktifä' fí akhbār alkhulafä’, ed. Felipe Maíllo Salgado, in Historia de Al-Andalus (Barcelona: Akal, 1986), 64-68; 134-137.

5 "In campo autem qui uoluerunt rapere plurima inuenerunt aurum, scilicet, argentum, uestes preciosas, suppellectilia serica et multa alia preciosissima ornamenta, necnon et pecunias multas et uasa preciosa." Roderici Ximenii de Rada, Historia de Rebus Hispaniae, ed. Juan Fernández Valverde, Corpus Christianorum Continuatio Mediaevaelis 72 (Turnhout: Brepols, 1987), 275 . 
The loot described in the chronicles proceeds not only from the war in alAndalus, although it does feature in the majority of references. In the so-called Latin Chronicle of the Kings of Castile, attributed to Juan de Soria, Chancellor of Fernando III (written 123os-124Os), the chronicler makes a generic mention of the famous sack of Constantinople by the Crusaders in 1204, when gold, silver, precious stones, and Syrian cloths of various kinds were wrested from its churches. ${ }^{6}$ Beyond looting, however, gifts, treaties, rewards, ransoms, theft, and commerce were also means of transfer of objects between Christians and Muslims. In general, we have only vague references in the chronicles to any of these means. For example, the De Rebus Hispaniae reports that an unnamed Muslim ruler of Toledo, who was planning to marry Teresa, the sister of Alfonso $\mathrm{v}$ of León (ca. 1008), changed his mind when struck by an angel after Teresa rejected his embrace, threatening him with the wrath of God. The king of Toledo then returned her to León accompanied by camels loaded with gold, silver, rich fabrics, and magnificent works of gold. ${ }^{7}$

The chronicles' accounts of the looting of churches by monarchs and nobles in the context of recurring conflicts among Christians offer regrettably few details of the objects pillaged, defining them by the material of which they are made rather than by any individual characteristic. Alfonso el Batallador, king of Aragon, was said to sacrilegiously steal gold, silver, and precious stones from places of worship in the Tierra de Campos because, according to De Rebus Hispaniae, he had no money to pay the army in his wars first against his estranged wife Queen Urraca and then her son, King Alfonso VII. ${ }^{8}$ Curiously, the archbishop-chronicler says nothing about what is highlighted by the documents from Urraca's reign, that is, the contributions of ecclesiastical institutions to the queen's demands to finance her war against Alfonso el Batallador. A charter from the Cathedral of Oviedo, for example, includes the gift of a valuable cup to the queen in 1112; a decade later, she received from the monasteries of León various objects of gold and silver, including chalices and

6 Crónica Latina de los Reyes de Castilla, ed. and trans. Luis Charlo Brea (Cádiz: Universidad de Cádiz, 1984), 46.

7 Roderici Ximenii de Rada, Historia de rebus Hispaniae, 167. The chronicle puts the following words into the mouth of the sister of the king of León: "I am a Christian and I loathe associating with strangers: do not touch me, lest the Lord Jesus Christ, whom I adore, strike you down." See also Simon Barton, "Marriage across Frontiers: Sexual Mixing, Power and Identity in Medieval Iberia," Journal of Medieval Iberian Studies 3/1 (2011): 1-25.

8 Roderici Ximenii de Rada, Historia de rebus Hispaniae: 222, "unde et rex Aragonum ad sanctuaria misit manum et thesauros auri et argenti et preciosorum palidum, quos regum et reginarum deuotio dedicarat, manu sacrilega usurpauit et etiam possessiones oblatas a regibus infiscauit." 
cups, cutlery and tableware, sacred rings, crosses, and an altar frontal. ${ }^{9}$ At the beginning of 1115, the queen ordered that the "silver" of the monastery of Valcabado, described as three vessels, a salt-cellar, and a cithara, be handed over to her officers; and at the end of 1116, she ordered the dismantling of a cross from the same monastery, which her aunt the Infanta Elvira had had made. ${ }^{10}$ Although such use of church treasuries must have been quite common at moments of crisis in all medieval Christian kingdoms, the extensive coverage of Urraca's pillaging in contemporary sources is directly related to her gender. Female power was seen as lacking legitimacy, a lack especially felt in the first half of Urraca's seventeen-year reign, and then again during the rocky first decade of the reign of her son Alfonso VII. At the death of Queen Urraca, ecclesiastical institutions such as the abbey of Sahagún rushed to claim from her son the return of the sacred objects appropriated by the queen, or at least compensation for the plunder. ${ }^{11}$

In these chronicles, the imprecise and generic nature of references to precious objects is striking. Also striking is the very scarcity of movable goods, compared to the constant references to property—land, churches, buildings of all types - in the narrative sources, and this despite the fact that the world of their authors-archbishops, bishops, clergymen and monks-was undoubtedly full of valuable objects. As the documentation makes clear, churches and

Irene Ruíz Albi, ed., La Reina Doña Urraca (1109-1126). Cancillería y colección diplomática, Fuentes y Estudios de Historia Leonesa, 102 (León: Centro de Estudios e Investigación San Isidoro, 2003), doc. 29, pp. 534-536: "est una copa argentea et deaurata, centum quinquaginta solidos ponderata, purissimo argento et opere obtimo fabricata;" doc. 125, pp. 761-764: "Et quia de proprio habere non potuit, per meam licenciam et canonicorum suorum tabulam altaris constantem nonaginta septem marcis argenti, et quamdam capsam continentem LX uncias auri, ab ecclesia sua comodatim accepit et mihi contulit, tali pacto, ut constituto tempore ecclesie sue restitueret."

10 Ruíz Albi, La Reina Doña Urraca, doc. 62, pp. 6o6-6o7. See Pascual Martínez Sopena, "La circulation des objets en temps de guerre. Les années de la reine Urraca (Leon et Castille, vers 1100-1130)," in Objets sous contrainte. Circulation des richesses et valeur des choses au Moyen Âge, ed. Laurent Feller and Ana Rodríguez (Paris: Publications de la Sorbonne, 2013), 257-282.

11 The idea that the kingdom had been devastated by Uraca's actions is found in some documents from the early months of her son's reign. Such is the case of the acknowledgment of goods received by the monastery of Sahagún from Alfonso VII in August 1126, where the twenty-one year old king presents himself as a child, ignorant, disturbed by adolescence, and corrupted by his mother and by her supporters (ubi a matre [...] infestatus). José Antonio Fernández Florez, ed., Colección diplomática del monasterio de Sahagún (León: Centro de Estudios e Investigación San Isidoro, 1991), IV:103-107. See also Ana Rodríguez, La estirpe de Leonor de Aquitania. Mujeres y poder en los siglos XII y XIII (Barcelona: Editorial Crítica, 2014), 216-217. 
monasteries received copious endowments of the goods needed to begin their institutional journey. These precious liturgical objects are listed in foundational documents, and it is logical to assume that they formed part of the daily life of monks, nuns, and clerics. ${ }^{12}$ In other words, the chroniclers were likely surrounded by objects, but in their writings they only chose to detail a few special pieces on particularly meaningful occasions.

Some examples are especially significant. Lucas de Tuy, author of the Chronicon Mundi and canon at the basilica of San Isidoro in León until the 1240s, must have encountered precious objects throughout his long ecclesiastical life at the royal church, many of which proceeded from the endowment of San Isidoro by King Fernando I and Queen Sancha in 1063, after the remains of the Visigothic bishop were translated from Sevilla. The surviving charter may not reflect a single document but rather a twelfth-century recasting of the juridical content of several royal documents, as has been discussed recently. ${ }^{13}$ The lengthy catalogue of possessions received by the church begins with a list of liturgical ornaments, gold- and silverwork, textiles, and tableware. It includes three golden crowns, one of them belonging to the king himself (or to the queen?):

one [of the crowns] with six alphas around it; another with pearls hanging within, and another golden one with pearls (amethysts? annemates) and enamels: in fact, the third one is the golden diadem from my own head ... ${ }^{14}$

12 For examples of monastic endowments with an abundance of precious objects and fine cloth from al-Andalus, see Ana Rodríguez, "A propos des objets nécessaires. Dotations monastiques et circulation d'objets dans le royaume de León dans le Haut Moyen Âge," in Objets sous contrainte. Circulation des richesses et valeur des choses au Moyen Âge, ed. Laurent Feller and Ana Rodríguez (Paris: Publications de la Sorbonne, 2013), 63-9o.

13 María Encarnación Martín López, "Un documento de Fernando I de 1063: ¿Falso diplomático?," in Monarquía y sociedad en el Reino de León: de Alfonso III a Alfonso VII, ed. José María Fernández Catón (León: Centro de Estudios e Investigación San Isidoro, 2007), 513-540. See also the discussion in Chpt. 2 of this volume by Therese Martin, "Caskets of Silver and Ivory from Diverse Parts of the World: Strategic Collecting for an Iberian Treasury."

14 "Offerimus [...] ornamenta altarium id est frontale ex auro puro opere digno cum lapidibus zmaragdiis saffiris et omni genere preciosis et olouitreis. Alios similiter tres frontales argenteos singulis altaribus. Cororonas [sic] tres aureas, una ex his cum sex alfas et corona de alaules intus in ea pendens alia est de annemates cum olouitreo atque tercia uero est diadema capitis mihi aureum et arcellina de cristallo auro cooperta, crucem auream cum lapidibus conpertam olouitream et aliam eburneam et similitudinem nostri redemptoris crucifixi, turibulos duos auris cum inferturia aurea et alium turibulum argenteum magno podere conflatum et calicem et patenam ex auro olouitreo, stolas aureas cum amoxerce argenteo et opera ex aureo et aliud argenteo ad amorcere habet opera olouitrea et capsam 
The richness of these crowns and other metalworks, as well as the gold and ivory crosses, the objects of silver and enamel — not to mention the precious emeralds, sapphires, and amethysts set within - is extraordinary, as befitted the place that would shortly become the royal pantheon, the center of both dynastic and symbolic power of the rulers of León until the kingdom's union with Castile in $1230 .{ }^{15}$

Of all the gifts given to San Isidoro, only an ivory cross, currently in the $\mathrm{Mu}-$ seo Arqueológico Nacional (Madrid), can with reasonable certainty be identified as part of that endowment because it bears the names of the royal donors. ${ }^{16}$ Although other objects from the list cannot be clearly identified with pieces still kept in the treasury of San Isidoro, what does seem clear is that this rich holding of liturgical goods made of gold and silver, precious stones, and ivory, must in some way have been viewed by those who lived inside the walls of San Isidoro. One of these inhabitants would have been Lucas de Tuy, whose chronicle lacks any description of the objects with which he was surely familiar. When his Chronicon Mundi relates the construction of the church of San Isidoro it simply mentions its decoration with gold, silver, precious stones, and silks. ${ }^{17}$ Clearly, the works that adorned the church in which he was canon for most of his life were not a priority in his account. It seems likely that, in the early thirteenth century when the canon of San Isidoro was writing, these objects no longer figured as important elements for the story of the future of the monarchy of León, despite their significance for rulers in the past.

Lucas de Tuy also refers, with the same lack of precision, to the richesgold, silver, and precious stones - presented by Fernando I to the Cathedral of San Salvador in Oviedo, although he had described in at least some detail the cross ex auro puro preciosisque gemmis ("a golden cross with precious gems") given by Alfonso III to that church. ${ }^{18}$ For his part, the Archbishop of Toledo,

eburneam operatam cum auro et alias eburneas argento laboratas: in una ex eis sedent intus tres alie capselle [...]." Ermine robes, liturgical vestments, Greek and Islamic textiles (alvexi) are also listed further on. The table service is made of silver. Also: "Omnia haec uasa argentea dearauta cum predicta arrotoma binas habent ansas." The arrotomas could be objects of rock crystal. Patrimonio cultural de San Isidoro de León:Documentos de los siglos X-XIII, ed. María Encarnación Martín López (León: Universidad de León, 1995), 26-29, doc. 6. The date on the document is 22 December 1063.

15 Therese Martin, Queen as King: Politics and Architectural Propaganda in Twelfth-Century Spain (Leiden: Brill Academic Publishers, 20o6).

16 Ángela Franco Mata, "El tesoro de San Isidoro y la monarquía leonesa," Boletín del Museo Arqueológico Nacional 9 (1991): 35-68. In the present volume, see Figures 2.4a-b and 6.6.

17 “... plurime pulcritudinis auro et argento lapidibusque preciosis et cortinis sericis decorauit," Lucas Tudensis, Chronicon Mundi, ed. Emma Falque Rey, Corpus Christianorum Continuatio Mediaevalis 74 (Turnhout: Brepols, 2003), 293. 
Rodrigo Jiménez de Rada, attributes particular value to objects given by kings to Oviedo as a source of the legitimacy of Toledo. When he speaks of the transfer to Asturias of the ark containing relics, sacred books, and the tunic of the Virgin in the eighth century, after the Islamic conquest, Rodrigo indicates that all this comes from Toledo and not from Sevilla as a way of reaffirming the metropolitan primacy of the see of Toledo in the face of the threat of the restoration of the old Visigothic sees. ${ }^{19}$ This was an imminent danger at the time of writing of De Rebus Hispaniae, just at the moment of the conquest of Cordoba (1236) and before that of Sevilla (1248):

It is said that the ark of the relics was built in Jerusalem and was transported by sea to Sevilla at the time of the persecution of the impostor Muhammed, and from there carried to Toledo, and that, finally, it was said, it was placed in Asturias.

And further on:

Whereupon, when the king (Alfonso II) was personally examining some precious stones, he thought of making a cross with gold and with those stones; and when he went from the church to the palace, two angels appeared before him under the guise of pilgrims saying that they were goldsmiths. Then the king, in addition to giving them gold and stones, provided them with a house where they could work in peace. And having sat down to eat, he sent some of his people to the goldsmiths, asking them who they were. When they arrived, they found an admirably finished cross that illuminated with its dazzling brilliance all the corners of the house [...] the king ... carried the glorious cross to the altar of the Savior; and, relating this to Leo III, who occupied the Apostolic See, he obtained from him permission for an archbishop to be created in the church of Oviedo. $^{20}$

\footnotetext{
19 On this topic and its impact on the writing of chronicles, see Peter Linehan, History and the Historians of Medieval Spain (Oxford: Clarendon Press, 1993).

20 Roderici Ximenii de Rada, Historia de Rebus Hispaniae, 125-126. "Ad hec cum rex preciosos lapides coram aspiceret, cogitauit crucem de auro et eisdem lapidibus fabricare, ipsique ab ecclesia ad palacium uenienti occurrerunt duo angeli in effigie peregrina se ese aurifices asserentes. Rex autem datis auro et lapidibus etiam dedit domum in qua possent secrecius operari. Cumque in prandio consedisset, misit nuncios ad aurifices sollicitans quinam essent. Cumque nuncii accessissent, inuenerunt crucem miro opere consumatam et corusco splendore tocius domus penetralia illustrantem, adeo ut non possent tantum splendorem intuencium oculi tolerare. Quod rex audiens festinauit, et tanto splendore
} 
This cross has been identified with the Cross of the Angels, preserved in the Cathedral of Oviedo, although very much transformed-almost converted into a replica-after the damage suffered in the Civil War of the 1930s, its theft in 1977 , and its later recovery in a very bad state of disrepair. ${ }^{21}$

Certain objects, however, did arouse the interest of the authors of the twelfth- and thirteenth-century Latin chronicles. In some cases discussed below, it is very possible that the chroniclers had seen the pieces, as they themselves affirmed; in others, their interest stems from a tradition coming from older accounts; and in almost all, the recounting of objects responds to the need to identify and to individualize in order to construct a particular narrative. A few objects emerge as fundamental narrative elements of the accounts in which they are included. And it is this that allows them to be individualized because their value is not only in the precious materials of which they are made or the specialized work needed for their manufacture, but even more in their ability to be bearers of - or to exemplify—personal and collective virtues or defects, and individual or family memories.

The Chronica Adefonsi Imperatoris offers a unique opportunity to discern the objects and relics that, as part of the sacred treasure, a monarch took along on military campaigns, a very common practice at the time. These liturgical goods were presumably used on portable altars, carried by clerics accompanying the royal armies, for the celebration of rites and ceremonies. According to this chronicle, Alfonso el Batallador, king of Aragon, always took with him on campaign a chest of pure gold adorned with precious stones inside and out; within was a cross made from fragments of the True Cross, which he had stolen in times of war from the monastery of Sahagún. ${ }^{22} \mathrm{He}$ also had ivory containers

comperto, agens gracias Saluatori, conuocato clero et populo et pontifice gloriosam crucem altare optulit Saluatoris, et ista referens Leoni tercio, qui sedi apostolice presidebat, optinuit ut in Ouetensi ecclesia archiepiscopus crearetur."

21 See Raquel Alonso Álvarez, "The Cruces Gemmatae of Oviedo between the Eleventh and Twelfth Centuries," Journal of Medieval Iberian Studies 9/1 (2017): 52-71.

22 "Habebat autem rex Aragonensium semper secum quandam archam factam ex auro mundo, ornatam intus et foris lapidibus pretiosis, in qua erat crux salutaris ligni, reliquiis veneranda, quo Dominus noster Ihesus Christus, Dei filius, ut nos redimeret suspensus est. In diebus autem bellorum rapuerat illam de Domo sanctorum martyrum Facundi et Primitivi, quae est in terra Legionis, circa flumen Ceiae. Et habebat pariter alias pixides eburneas coopertas auri, argento et lapidibus pretiosis, plenas reliquiis sancte Marie, el ligni Domini, apostolorum, martirum et confessorum, uirginum, patriarcharum et prophetarum; erantque reposite in tentoriis, ubi erat capella que semper iuxta tentoria regis adiacebat, easque cotidie uigilantes sacerdotes et leuite et magna pars clericorum obseruabant semperque offerebant super eas sacrificium Domino Deo ..." Chronica Adefonsi Imperatoris, 174. Note that the chronicles state that the theft was by Alfonso, not Urraca. 
covered with gold, silver, and precious stones that were filled with relics of the Virgin, more fragments of the True Cross, and relics of apostles, martyrs, and confessors, virgins, patriarchs, and prophets. This treasure was guarded in the tents containing the king's chapel, which was always situated next to the royal apartments; his priests, deacons, and clergy watched over them and used them for the celebration of mass.

But at the battle of Fraga of 1134 as punishment for his sins (among which, one imagines, was the robbery of relics from Sahagún), the Muslims took possession of the king's golden chest and the ivory containers with all the riches and relics they contained, knocking down the royal tents and storming the chapel. Alfonso el Batallador fled the battlefield with some of his faithful men and, sick at heart—says the chronicle — he died a few days later. ${ }^{23}$ Subsequently, the Estoria de España of Alfonso X, which repeatedly presents the king of Aragon as the instigator of unbearable violence, tells in one of its chapters how the king deceived the sacristans of the monastery of Sahagún in order to steal the True Cross, the most important of their relics. In another we read how he further planned to rob within the monastic enclosure, using his own brother Ramiro, "a false and evil monk," say the authors of this Alfonsine historiographical work:

Ramiro had the whole wealth of the monastery brought before him [...], to wit, carpets, pillows, blankets, quilts, sheets, gold and silver vessels, reliquaries full of holy relics, and church ornaments of great riches [...], among which things he took a finger of Mary Magdalene, some crosses of gold, and precious stones, and in their place put plaster and dog bones. ${ }^{24}$

As noted above, portable altars and relics accompanied rulers on their journeys and military campaigns. Jaime I of Aragon entered Mallorca in 1229 accompanied by the relics that he had hoarded; a reliquary in the shape of a silver book, which has traditionally been identified with the portable altar used during Jaime's campaigns, is still preserved in the cathedral of Palma. Composed of two

23 Chronica Adefonsi Imperatoris, 176-177.

24 "Ramiro hizo traer a su presencia toda la sustancia del monasterio ..., conviene a saber tapetes, almohadas, cobertores, cocedras, savanas, vasos de oro e de plata, custodias llenas de reliquias santas, e ornamientos de la Iglesia de muchas riquezas [...] Entre las cuales cosas tomó un dedo de la Magdalena, llevó unas cruces de oro, llevó piedras preciosas e en su lugar puso yeso y hueso de perro." Primera Crónica General de España que mandó componer Alfonso el Sabio y se continuaba bajo Sancho IV, ed. Ramón Menéndez Pidal (Madrid: Gredos, 1955), 313. Ramiro II el Monje succeeded his brother Alfonso I as king of Aragon in 1134 . 
leaves divided into twenty-four squares containing twenty-four relics of Christ, the Virgin, and saints, this diptych may indeed be from that period with additions from the early years of the fourteenth century. ${ }^{25}$

Certain objects appear in chronicles because they have special importance for the rituals of medieval Christian monarchies. Despite the very scarce evidence for coronation ceremonies in Castilla-León during the central Middle Ages, a fact that has given rise to an intense debate in the historiography on rituality and sacred elements in the mediaeval Hispanic monarchy, references to the crowns themselves are fairly abundant in the chronicles. ${ }^{26}$ The crown is a central element in the account in De Rebus Hispaniae concerning the legitimacy of Visigothic power, a legitimacy that the archbishop of Toledo, Rodrigo Jiménez de Rada, sought to elide with that of the Castilian monarchy-socalled neogothicism-ignoring the dynastic break caused by the end of the Visigothic kingdom in 711. After the rebellion of Duke Paul in Narbonne in 673 and his defeat by King Wamba, the rebel returned the sacred objects that had been stolen:

For the traitor Paul, fearful of being deprived of the funds which he had received from the king, increased them by robbery in sacred places, and sacrilegiously seized as many vessels of gold and silver as he could obtain from the treasuries of the Lord. In his madness, he even wore on his head the golden crown that the very devout King Recaredo had offered in Gerona to the altar of Saint Felix. Thereupon, King Wamba stipulated that the sacred vessels he was able to find should be returned to their respective churches. ${ }^{27}$

The crown of Recaredo has not survived, but it cannot have been very different from those in the treasure of Guarrazar displayed today in the Museo Arqueológico Nacional in Madrid. ${ }^{28}$ The cruel punishment meted out to Paul and

25 José Miralles Sbert, Las reliquias y relicarios de la Catedral de Mallorca (Palma de Mallorca: Monumenta Maioricensia, 1961).

26 The two opposing positions in the debate are developed by José Manuel Nieto Soria, "Origen divino, espíritu laico y poder real en la Castilla del siglo XIII," Anuario de Estudios Medievales 27 (1997): 43-102; Nieto Soria, Fundamentos ideológicos del poder real en Castilla (siglos XIII-XVI) (Madrid: Eudema, 1988); Teófilo Ruiz, "Une royauté sans sacré: la monarchie castillane du Bas Moyen Âge," Annales E. S. C. 39 (1984): 429-453; Peter Linehan, "Frontier Kingship. Castile 1250-1350," in La royauté sacrée dans le monde chrétien. Colloque de Royaumont, mars 1989 (Paris: École des Hautes Études en Sciences Sociales, 1992), 71-79.

27 Roderici Ximenii de Rada, Historia de rebus Hispaniae, 88.

28 See Alicia Perea, ed., El tesoro visigodo de Guarrazar (Madrid: CSIC, 2001). 
his companions for their betrayal was accompanied in the duke's case by a symbolic crown; the account says that they were imprisoned in Toledo, making their entry into the city:

... after having their heads shaved, their beards shaved off, barefoot, clothed in sackcloth, mounted on camels, and Paul, for greater dishonor, crowned with a fish spine, following the long line of his men whom he had pushed into blindness [literally; they were imprisoned after being mocked with the humiliation of having their heads shaved - anyone suffering this punishment could not be king, according to canon XVII of the IV Council of Toledo — and their eyes put out] and treason, becoming the general object of derision, jest, and mockery. ${ }^{29}$

The archbishop of Toledo later describes other crowns, as at the battle of Guadalete in 711. King Rodrigo

with a crown of gold and a garment embroidered with the same metal was carried on a bed of ivory drawn by two mules, as required by the protocol of the Gothic kings. ${ }^{30}$

In the course of the battle where Almanzor confronted the Christian kings in Rueda or Roa (983-984), he "took off a gold cap that he wore as a crown, rose from his chair and sat on the ground, according to the custom of the princes of his people." ${ }^{31}$ Fernando I, at the time of his death, stripped himself of crown and royal tunic before the reliquary of Saint Isidore in León. ${ }^{32}$ Elsewhere, the Chronica Adefonsi Imperatoris relates the imperial coronation of Alfonso VII in 1135: the king, dressed in a splendid cloak woven with admirable craftsmanship, received on his head a crown of pure gold and precious stones. ${ }^{33}$

29 Roderici Ximenii de Rada, Historia de Rebus Hispaniae, 9o: “decaluatis capitibus, rasis barbis, pedibus denudatis, induti saccis, camelis impositi, et Paulus confusionis pocior corona picea coronatus, sequente longa deductione suorum quos cecitas et proditio producebat, facti omnibus in ludibrium et derisum, in obprobium et cachinnum."

Roderici Ximenii de Rada, Historia de Rebus Hispaniae, 102-103: "cum corona aurea et uestibus deauratis a duobus mulis in lecto eburneo ferebatur, ut Gothorum regum dignitas exigebat."

31 Roderici Ximenii de Rada, Historia de Rebus Hispaniae, 163: "deposito aureo pilleo quem pro corona gestabat, humi resedit iuxta morem principum gentis suis."

32 Roderici Ximenii de Rada, Historia de Rebus Hispaniae, 194: "et imposito capiti diademate et indutus regalibus indumentis coram sarcofago sancti Ysidori." 
In spite of all these written references, it is striking that the only crown to have survived as a material object from the central Middle Ages in the kingdoms of Castile and León is that from the tomb of King Sancho IV, who had been crowned and later buried in Toledo cathedral. Sancho's coronation was featured in the first lines of the chronicle of his reign. ${ }^{34}$ The crown consists of eight rectangular metalwork plates or links joined by hinges and bordered by a simple molding. Each segment is surmounted by a castle. It is completed with four sapphires and four cameos, two Roman and two Staufen. ${ }^{35}$ We find evidence of the existence of crowns with cameos in the will of Alfonso X, written in Sevilla in January 1284: "and the crowns with stones and cameos [....] may be held by anyone who rightfully inherits our greater lordship of Castile and León," from which we can recognize the presence of more than a single crown with cameos among this monarch's treasures. In terms of its technical manufacture, Sancho's crown is a minor example of metalworking, which may indicate that when arranging funeral goods an effort was made to avoid burying works of high quality or special significance. Thus, it would be appropriate for a dead king to wear a crown that, for its lower material quality, was of lesser use for the public acts of a living monarch. ${ }^{36}$

In the chronicles, objects generally appear linked to specific places, but they may circulate in very different ways. A revealing example of what Arjun Appadurai called "the social life of things" 37 centers on the travels of an object that was initially owned by Zafadola - a linguistic corruption of Sayf al-Dawla, "Sword of the Dynasty" - who was to be the last king of the taifa of Zaragoza, vassal of Alfonso VII, and one of the participants in the latter's imperial coronation of 1135. Lucas de Tuy's Chronicon Mundi (and also Jiménez de Rada's De Rebus Hispaniae, although with some variations, as we shall see below) attributed the motive of the pilgrimage to Santiago by King Louis VII of France,

34 "É luego fuese para Toledo, é fizose coronar á él é a la reina doña María, su mujer; e coronáronlo cuatro obispos ..." ("And then he went to Toledo, and had himself and Queen María crowned, and four bishops crowned him ...") Crónica del Rey Don Sancho, el Bravo, fijo del Rey Don Alfonso X, in Crónicas de los reyes de Castilla, desde Don Alfonso el Sabio hasta los católicos Don Fernando y Doña Isabel, ed. Cayetano Rosell, 3 vols. (Madrid: BAE, 1961), I:69; Isidro G. Bango "La llamada corona de Sancho IV y los emblemas de poder real," Alcanate 9 (2014-2015): 261-283.

35 Wilhelm Grünhagen, "Bemerkungen zu den Kameen in der Krone des Königs Sancho IV von Kastilien," Madrider Mitteilungen 29 (1988): 245-253.

36 Bango, "La llamada corona de Sancho IV y los emblemas de poder real," 28o. The author's contention that the crown of Sancho IV was "a minor example of metalworking" has not received complete acceptance in the bibliography.

37 The Social Life of Things. Commodities in Cultural Perspectives, ed. Arjun Appadurai (Cambridge: Cambridge University Press, 1986). 
married in 1154 to Constanza, daughter of Alfonso VII, to his desire to verify whether his wife was the daughter of the ruler's concubine, as had been insinuated. The two monarchs met in Burgos. Alfonso vir made a show of all his power and wealth, and he offered Louis VII "a profusion of gifts, each more valuable than the last; but Louis would only accept a great emerald (zmaracdum magnum) that King Zafadola had given to his lord Alfonso VII." ${ }^{38}$ Lucas de Tuy then notes that when Louis returned to France, he presented this precious jewel to the abbey of Saint Denis.

Rodrigo Jiménez de Rada's account makes the same point as Lucas de Tuy about the motivation that led Louis to make his pilgrimage to Santiago and to meet with his Castilian counterpart, and it also coincides in pointing out the abundance of wealth offered by Alfonso. However, it adds some significant details while omitting others:

The emperor [Alfonso VII] offered him a profusion of gifts, each more valuable than the last; but Louis would only accept a carbuncle, which he placed in the crown of thorns in Saint-Denis, which I remember seeing. ${ }^{39}$

De Rebus Hispaniae omits any reference to Zafadola, the first owner of the gem, while disagreeing with the Chronicon Mundi about what type of gemstone it was: a green emerald according to Lucas de Tuy, a carbuncle or red ruby according to the Archbishop of Toledo. It seems likely that Jiménez de Rada would have been able to distinguish between a ruby and an emerald: a chapter later he recounts the conquest of Almería by the Genoese, who received all the regal booty including a container of emeralds. ${ }^{40}$ Two new pieces

38 Falque, Lucas Tudensis, Chronicon Mundi, 315. "Multa donaria oblata fuerunt tunc nobilissimo Lodoico regi Francorum, sed nichil inde accipere uoluit, nisi quendam zmaracdum magnum [lapidem preciosum] cogente imperatore Adefonso, quem rex Zafadola detulerat. Reuersus est itaque rex Lodoicus in Franciam cum honore et leticia magna et hunc preciosum lapidem, quem detulerat ab Yspania monasterio beati Dionisii contulit." Georges Martin, "L'escarboucle de Saint-Denis, le roi de France et l'empereur des Espagnes," in Saint-Denis et la Royauté. Études offertes à Bernard Guenée, ed. Françoise Autrand, Claude Gauvard, and Jean-Marie Moeglin (Paris: Publications de la Sorbonne, 1999), 439-462, tracks the transmission of the story through the different narrative sources of the thirteenth century. As Martin rightly points out, the Chronica Adefonsi Imperatoris, begun in the lifetime of Alfonso VII, and which inspired Lucas de Tuy for certain details, does not contain this episode.

39 Roderici Ximenii de Rada, Historia de Rebus Hispaniae, 230: "Optulit eadem imperator infinita donaria, que sui ualore numerum excedebant; set nil eorum uoluit recipere Lodouicus, nisi quondam carbunculum, quem in corona spine Dominice apud Sanctum Dionisium collocauit, quem etiam memini me uidisse."

Roderici Ximenii de Rada, Historia de Rebus Hispaniae, 232. 
of information, however, are of particular interest: first, this is the personal testimony of Jiménez de Rada-one of several in his chronicle-who tells us that he remembers seeing the gem in Paris, where he received training in theology before assuming the archbishopric of Toledo. Secondly, the mounting of the jewel in the Holy Crown, a magnificent work of gold destined to house the relics of Christ's crown of thorns; this reliquary was melted down in April 1794, although drawings were made prior to its destruction. ${ }^{41}$ Of the stones that were extracted before the crown-reliquary was dismantled, there is only mention of a Syrian garnet that had belonged to Anne of Kiev, wife of King Henry I of France. ${ }^{42}$

Zafadola, who probably gave the gem to Alfonso VII as proof of his vassalage, was in turn the son of 'Imād al-Dawla, "Supporter of the Dynasty," an ally against the Almoravids of the king of Aragon, Alfonso el Batallador, with whom he took part in the Battle of Cutanda in 1120. Imād al-Dawla is almost certainly the Mitadolus whose name appears inscribed on the silver-gilt foot of a rock crystal vase, which itself probably had come from the sacking of the Fatimid palaces of Cairo in the 106os. Now known as the Eleanor Vase, this luxurious object was also part of the treasury of Saint Denis, and it is currently held by the Musée du Louvre. ${ }^{43}$ The well-known inscription on the base reads, "As a bride, Eleanor gave this vase to King Louis, Mitadolus to her grandfather, the king to me, and Suger to the saints." This text traces the route of the object: Mitadolus, ruler of Zaragoza, gave it to William IX of Aquitaine, probably when both were in the service of Alfonso el Batallador, king of Aragon; William of Aquitaine gave it to his granddaughter Eleanor, perhaps as a baptismal gift, who in turn gave it to her husband, Louis VII; and he gave it to Abbot Suger of Saint Denis, in whose treasury it would long be held. De Rebus in

41 The old drawings of the crown and the descriptions of the precious objects that were part of the treasure of Saint-Denis were published in the catalogue of the exhibition that took place in the Musée du Louvre in 1991. See Daniel Alcouffe et al., Catalogue de l'Exposition: Le trésor de Saint Denis (Paris: Réunion des Musées Nationaux, 1991). The crown of St. Louis is also mentioned in the 1634 inventory of the goods at the church of Saint Denis: Marie-Madeleine Gauthier, "Le trésor de Saint-Denis. Inventaire de 1634," Cahiers de Civilisation Médiévale 18 (1975): 149-156.

42 Georges Martin suggests that, as a way of enhancing royal prestige, Jiménez de Rada identifies one of the garnets of the Crown of Thorns he saw at Saint-Denis-perhaps that of Anna of Kiev? - with the precious stone given by Alfonso VII. This episode, with some additions, is repeated in the Historia de España of Alfonso X.

43 George T. Beech, "The Eleanor of Aquitaine Vase, William IX of Aquitaine, and Muslim Spain," Gesta 32 (1993): 3-10; Beech, "The Eleanor of Aquitaine Vase," in Eleanor of Aquitaine. Lord and Lady, ed. Bonnie Wheeler and John Carmi Parsons (New York: Palgrave Macmillan, 2003), 369-373. See also Rodríguez, La Estirpe de Leonor de Aquitania, 133-188. 
administratione sua gestis, a work composed by Abbot Suger between 1144 and 1148, which describes the enlargement of Saint-Denis and the way in which the abbey's treasure had been accumulated, makes reference to several ewers, some donated by the magnates of the kingdom, and others acquired. Notable among them was the Eleanor Vase:

Also a vessel, a kind of carafe of beryl or crystal with the capacity of a pint, which the newly married Queen of Aquitaine had given to our Lord King Louis on his first voyage, and the present King to us as an index of his affection, we offered it in turn to our masters the holy martyrs for the sacrifice of the table of God. We ordered the story of the donation to be engraved on the vessel itself, once it had been adorned with gold and precious stones, in these few lines: Eleanor, the bride, gave this vessel to King Louis, Mitadolus to her grandfather, the King to me, and Suger to the saints. ${ }^{44}$

Surprisingly — and unlike the colorful jewel of the Crown of Thorns reliquarythere is no trace of the Eleanor Vase in chronicles from Spanish lands, despite its prominence in French accounts. Perhaps the reason for this absence lies in the fact that there was no royal intermediation in the transmission of the precious object and that it was therefore not possible to construct a narrative about the power of the Castilian kings and the obligations of their vassals, as reflected in gifts of material goods of great value. Nevertheless, both objects, the gem of Zafadola and the Fatimid rock crystal ewer of Mitadolus ended up in the treasury of the great Parisian abbey of Saint Denis. It is also significant that both had been presented by King Louis VII of France after receiving them from his two wives: the vase from the first, Eleanor; the gem from the second, Constanza.

As we have seen, most of the objects described in any detail in the chronicles of the kingdoms of Castile and León during the twelfth and thirteenth centuries have an intrinsic value derived from the precious materials of which they are made, the production techniques, the function for which they are conceived or that they acquire as symbols of power and, on many occasions, the long journey from their places of origin to the ecclesiastical or royal treasuries where they end up. We read of Syrian textiles, Andalusi silks, Fatimid rock crystal, ivory, and gold- and silverwork on various liturgical implements.

44 Abbot Suger and the Abbey Church of St Denis and Its Art Treasures, ed. Erwin Panofsky (Princeton: Princeton University Press, 1946), chapter XXXII: "Hoc vas sponsa dedit Aanor regi Ludovico / Mitadolus avo, mihi rex, sanctisque Suger." 
Demand, as the basis of real or imaginary exchange, also endowed the objects with value by setting the parameters of utility and scarcity. In this sense, few objects were more in demand at that time than relics, whose circulation in the Middle Ages reflects an essential element in the construction of an ecclesiastical community's identity and prestige, both local and on a larger scale. The movement of relics also shows the rivalries between different institutions as they sought to garner the power of objects whose value was determined by their written or oral history and by the verification of that history, as well as by forms of exchange outside the paths established for non-sacred goods. Given these specific conditions of demand for medieval relics, it is not surprising that their transfer from place to place often came about through theft. ${ }^{45}$

Castilian chronicles deal with the circulation of relics and sacred goods by way of theft in two different ways. In the first case, when the individual who has taken the holy spoils by force is secular: as we have already seen, during the reign of Wamba the traitor Paul committed sacrilege, which eventually led to him being paraded around Toledo crowned with a fish spine. Sacrilegious, too, were the actions of Alfonso el Batallador, whose defeat at Fraga against the Muslims is interpreted as a divine punishment for having stolen the True Cross and other relics from the monastery of Sahagún, leaving - in the addition found in the Estoria de España-plaster and dog bones in their place. These laymen who steal church treasures and relics, even if they make use of the liturgical goods on their own portable altars, are roundly condemned in the medieval narrative sources.

In the second case, when those who resort to theft are archbishops, bishops, or abbots, the assessment of the situation by other ecclesiastics who wrote the Castilian chronicles is quite different. In contrast to the castigation of Christian kings and nobles who took sacred goods by force, the ecclesiastics' acquisition by theft of relics that they considered necessary to endow their own houses with legitimacy and prestige is presented as a valid form of exchange. These are the furta sacra studied by Patrick Geary, a way of obtaining relics that was as desirable as donation and rather moreso than the commercial trade for other types of precious objects: ${ }^{46}$ it was more representative, in short, of their real value and effectiveness. In general, the narrative sources analyzed in the present article are not specific when dealing with the acquisition of relics by

45 Patrick Geary, "Sacred Commodities: The Circulation of Medieval Relics," in The Social Life of Things. Commodities in Cultural Perspectives, ed. Arjun Appadurai (Cambridge: Cambridge University Press, 1986), 169-191.

46 Patrick Geary, Furta Sacra: Thefts of Relics in the Central Middle Ages (Princeton: Princeton University Press, 1991). 
the great episcopal sees, rather incorporating discourses found elsewhere. On some occasions, however, they may explain how a given ecclesiastical institution acquired its relics, and theft provides some of the most detailed accounts.

The Historia Compostellana, written between 1107 and 1149 to the greater glory of Archbishop Gelmírez of Santiago de Compostela, is particularly voluble in this respect when it narrates, for example, the traslatio of Saints Fructuoso, Silvestre, and Cucufate in 1102 from Braga to Santiago. The author of this part of the chronicle directly admits that the acquisition was "pious larceny" (pio latrocinio).

And because San Fructuoso was the defender and patron of that region, he took him most fearfully and silently, with pious larceny, from the church that he had built when he was still alive, and when he had done so, he handed him over to the care of his faithful guardians [...] Once dawn broke and he knew that what he had done had not become known, he returned as quickly as if in flight, and full of joy and happiness carried his hidden treasure to a town of Santiago called Cornelhá. ${ }^{47}$

The account takes a similar form when it traces the itinerary of the head of Santiago (St. James), stolen in Jerusalem by Bishop Mauricio de Braga: the envoys of the bishop approached the altar with mattocks, dug deep, and found a vessel of ivory and inside it another silver one full of relics. Then they fled. This pious larceny, as it were, reached Iberia and was deposited in San Zoilo de Carrión de los Condes; from there Queen Urraca took it and other relics-among them a fragment of the Holy Sepulcher and a bone of Saint Stephen - to San Isidoro de León. Then the queen gave the head of St. James to Archbishop Gelmírez, who solemnly entered the town of Santiago with it in $1116 .{ }^{48}$ In the second book of the Historia Compostellana there is an inventory of everything

47 Historia Compostellana, ed. Emma Falque Rey, Corpus Christianorum Continuatio Mediaevaelis, 70 (Turnhout: Brepols, 1988), 34: "Sed quoniam sanctus Fructuosus regionis illius defensor et patronus erat, cum maiore timore et silentio de ecclesia sua, quam ipse adhuc uiuens in carne fecerat, eum pio latrocinio sustulit et sublatum fidelibus suis custodibus seruandum commisit [...]." The author of this story refers to the theft of the relics by Gelmírez from Braga in 1102 and their subsequent secret transfer to Santiago as "traslatio." Other narrative sources tell the same kind of stories; as Geary notes in "Sacred commodities," 183-184: "The usual target of the isolated theft was a distant monastery or church visited by a cleric who, judging that the saints whose relics were there were not receiving proper veneration, entered the church at night, broke open the shrine, and fled with the remains."

48 Falque, Historia Compostellana, 193-194: "Quedam denique nocte tempestiua ceteris absentibus, clauso ecclesie hostio, aggrediuntur altare ligonibus, quos secum furtim attulerant, et fodientes in altum sub altari, sicut audierant, inueniunt uas quoddam eburneum 
the archbishop acquired for his church: from liturgical garments to silver and gold gospel books, gold and silver boxes with crystal inlay, a silver Lignum Crucis given to him by Queen Urraca, and a silver casket that is distinguished from the rest because it is said to hold the head of Santiago. ${ }^{49}$

The rivalry between the archiepiscopal sees of Santiago and Toledo had important consequences for the organization of the Hispanic church and for the hierarchy among the dioceses after the union of the kingdoms of Castile and León in 1230. This conflict had previously been embodied in the tale of the robbery of a precious object disguised as a forced donation. During Gelmírez's rule as archbishop, the author of the third book of the Historia Compostellana recounts the obtaining by Santiago of a gold chalice for which the archbishop paid, through his treasurer, a hundred marks of pure silver to King Alfonso VII, who in turn had bought it from the archbishop of Toledo "at a time when he was in need."50 Gelmírez's treasurer then stayed in the royal court before departing on pilgrimage to Jerusalem. The court was probably in residence in Toledo at that time because it was in the Cathedral of Toledo that the treasurer saw a valuable ewer of beautifully worked crystal. As he knew that the archbishop of Toledo was very fond of this object, and he feared that he would refuse to give it as a gift, the treasurer secretly whispered in the ear of the king to ask the archbishop for it, and then to give it to him. And the king did so, says the Compostellana, because this treasurer was also the king's chancellor, thanks to the influence exerted by Gelmírez. Once he had acquired the ewer, he carried it off to the church of Santiago.

In sum, accounts of objects of daily use exchanged for others of greater value; transfers of luxury goods from Islamic to Christian contexts, and in the course of that process become sanctified, like chalices or reliquaries; gems and rock crystals whose intrinsic value is enhanced by the prestige of their former

et intus aliud argenteum plenum reliquiis. Quod accipientes discedunt cum episcopo suo noctu et adeunt ciuitatem sanctam Iherosolimam fugientes ...”.

49 Falque, Historia Compostellana, 333. The inventory testifies to the enormous wealth of the archbishop's seat. The long list includes a gospel book of purple, two of silver and one of gold, a silver missal, a silver epistolary, a gold belt, "two silver caskets, in one of which is said to be the head of Santiago (capsas II argenteas, in una quarum perhibetur esse caput beati Iacobi), another ivory casket, another of gilded metal sculpted with admirable artifice with inlaid crystal, another precious gold casket which the archbishop bought for three thousand sueldos and then gave to the Holy Father Pope Callixtus, a silver Lignum Crucis, given by Queen Urraca, daughter of King Alfonso."

50 Falque, Historia Compostellana, 433: "quendam calicem aureum honorabilem et pretiosum, in quo septigenti morabitini continebantur, quem ipse rex A. toletano archiepiscopo imminente sibi necessitate acquisierat." 
owners; sacred objects whose value lies not in their beauty but in being essential elements in the construction of identity and sources of power: all of these appear in the Castilian and Leonese chronicles written during the central Middle Ages. These forms of exchange-donation, purchase, theft_-allow us to establish ideas about their nature and inalienable character, while the details in some descriptions bring us closer to a real world of objects that were seen and remembered, if only rarely set down in writing.

These textual accounts deal in diverse ways with the objects that formed part of the daily ritual life of the chronicles' authors, all of whom were clerics. As we can conclude from the present discussion about what the texts sayand what they silence-the authors' criteria when individualizing certain objects in the recounting of their tales was not necessarily related to familiarity, as evidenced particularly by the meager interest of Lucas de Tuy in the treasury of San Isidoro de León, where he was canon and within whose walls he wrote his Chronicon Mundi. Nor, in the majority of cases, was it related to the idea of extolling the victories against the Muslims of al-Andalus. Rather, the enormous wealth and extravagance of what could be obtained as booty, for example, was measured by the quantity of goods and by the value of their materials - gold, silver, rich textiles from Andalusi workshops - and not in the specificity of a given object that might deserve a detailed description. Only as partial fragments of larger texts, whose main purpose was to elaborate a narrative linked to the construction of royal power, is a more detailed sketch considered necessary. What made such objects deserving of inclusion in a story was not, therefore, their intrinsic value. It was rather their ability to evoke deeds and circumstances whose protagonists were not the things themselves but, fundamentally, the content and form of the multiple relationships forged in a process of exchange. In this way, a precious few objects were able to become, in the histories in which they were featured, essential elements of the narrative.

\section{Acknowledgments}

Republication of this study in the present volume was supported by the Index of Medieval Art (Princeton University) and The Medieval Iberian Treasury in Context: Collections, Connections, and Representations on the Peninsula and Beyond (National Research Challenge Grant, Spanish Ministry of Science, Innovation, and Universities, AEI/FEDER, RTI2018-o98615-B-Ioo, 2019-2O22, PI Therese Martin). 